\title{
Quantitative and Qualitative Analysis of Human Stromal Vascular Fraction from Different Methods of Liposuction Short Title: Stromal Fraction from Liposuction Types
}

Luiz Fernando Frascino ${ }^{1}$ and Idiberto Jose Zotarelli Filho ${ }^{2^{*}}$

${ }^{1}$ Plastic Surgery Departament, Heart Hospital, Institute of Cardiovascular Diseases, Sao Jose do Rio Preto-SP (HC-IMC), Frascino Institute of Plastic Surgery, Sao Jose do Rio Preto-SP, Sao Paulo, Brazil

${ }^{2}$ Domingo Braile Institute of Sao Jose do Rio Preto (SP), Luiz Vaz de Camoes Street, Redentore Village, Sao Jose do Rio Preto-SP, Sao Paulo, Brazil

\begin{abstract}
Background: Although the widespread use for harvesting fat, liposuction is not represented by a single procedure and, in the absence of evidence based guidelines regarding cell based therapies, different protocols may be employed to extract the Stromal Vascular Fraction (SVF) and its cellular subpopulations. Usually the tissueharvesting procedures has been underestimated as a factor to impact the outcomes.
\end{abstract}

Methods: 4 methods of liposuction were employed in triplicate in 16 patient candidates for liposuction:

- Manual liposuction with $10.0 \mathrm{~mL}$ Luer-Lok syringe and $2.0 \mathrm{~mm}$ blunt tip cannula

- Manual liposuction with $60.0 \mathrm{~mL}$ syringe and $2.5 \mathrm{~mm}$ cannula

- Power-Assisted Liposuction (PAL) (Vibrofit $\Theta$ - Faga Medical) set at 3.000 cycles and $3.0 \mathrm{~mm}$ cannula and

- $\quad$ Suction-Assisted Liposuction (SAL) ( Nevoni® 3003 model) and $4.0 \mathrm{~mm}$ cannula

They were divided in 3 groups, according to the aspirated volume:- group I: $20.0 \mathrm{~mL}$, group II: $60.0 \mathrm{~mL}$ and group III: $120.0 \mathrm{~mL}$, obtaining 48 samples for analysis. Cellular quantification, viability and mesenchymal characterization was performed in the extracted SVF in all samples and the results were compared by Pearson statistical test and logistic probability, adopting a significant level above 0.05 ( $\alpha>0.05)$.

Results: The worst cell yielding was obtained with SAL and $4 \mathrm{~mm}$ blunt tip cannulas in all volumes. The manual method with $10.0 \mathrm{~mL}$ seringe $/ 2.0 \mathrm{~mm}$ cannula and PAL/3.0 mm cannula showed better cellular SVF extraction in all groups, with no differences statistically significant between them. The cell frequencies of these best scores showed an exponential increase with increasing volumes from 2.900 .000 cells $/ 20 \mathrm{~mL}$ group to $18.500 .000 / 60 \mathrm{~mL}$ group $(6.4 \mathrm{xx})$ and to $380.000 .000 / 120 \mathrm{~mL}$ group $(20.5 \mathrm{xx})$.

Conclusion: The mechanical stress applied over the subcutaneous tissue may impact the cell yielding of the extracted SVF. Syringes with small cannulas $(2.0 \mathrm{~mm})$, and/or in-vivo emulsification of the adipose tissue through PAL seem to have a positive effect, optimizing future liposuction protocols.

Keywords: Liposuction; Stromal vascular fraction; Mesenchymal stem cell; Guideline protocol

Abbreviations: PAL: Power-Assisted Liposuction; SAL: SuctionAssisted Liposuction; SVF: Stromal Vascular Fraction; ADSCs: Adipose-Derived Stem Cells; MSCs: Mesenchymal Stem Cells; BMI: Body Mass Index

\section{Introduction}

The identification of multipotent cells within the adipose tissue, then named Adipose-Derived Stem Cells (ADSCs) [1], have opened a new promising field in fat biology and into the frontiers of regenerative medicine [2]. After decades dealing with liposuction and fat grafting $[3,4]$, we are able to harvest fat tissue in almost any desirable volume, representing an unprecedented source of stem cells.

The practical application of cell-based therapy is still limited and under regulations [5], but seems to be a one-way road for several diseases and in the field of tissue engineering [6]. Hundreds of articles about cells extraction to therapeutic purposes have been published in all specialties employing the total SVF or isolated ADSCs with promising outcomes.

These multiple potential applications insert a concern about the quality and quantity of the aspirated subcutaneous fat as a source of donor cells. Although the widespread use for harvesting fat, liposuction is not represented by a single procedure and, in the absence of evidence based guidelines, different protocols may be employed with the same purpose using all the fat obtained [7] or even just the saline/blood fraction of the lipoaspirates [8] but usually the tissue-harvesting procedures has been underestimated as a factor to impact the outcomes.

Another discussion is the possibility of fast SVF extraction and application [9], allowing a one-step procedure without cell manipulation,

*Corresponding author: Idiberto Jose Zotarelli Filho, Domingo Braile Institute of Sao Jose do Rio Preto (SP), Luiz Vaz de Camoes Street, Redentore Village, Sao Jose do Rio Preto-SP, Sao Paulo, Brazil, Tel: +55(17)4009-3939; +55(17) 81666537; E-mail: scientific@institutodomingobraile.com.br/m.zotarelli@gmail.com

Received September 05, 2018; Accepted September 28, 2018; Published October 04, 2018

Citation: Frascino LF, Filho IJZ (2018) Quantitative and Qualitative Analysis of Human Stromal Vascular Fraction from Different Methods of Liposuction Short Title: Stromal Fraction from Liposuction Types. Stem Cell Res Ther 8: 439. doi: 10.4172/2157-7633.1000439

Copyright: (c) 2018 Frascino LF, et al. This is an open-access article distributed under the terms of the Creative Commons Attribution License, which permits unrestricted use, distribution, and reproduction in any medium, provided the original author and source are credited. 
preserving all the cellular components of the extracted SVF and eventually favoring its biological behavior at the transplanted site.

Also the laboratorial protocols for extracting the SVF must be properly evaluated, from simple cells counting up to its characterization as mesenchymal tissue, as well as employing enzymatic tissue digestion through collagenases, limited by the presence of possible xenogeneic components, witch pose certain risks and safety issues to clinical scenarios [10].

The objective of this article was to analyze the cell frequencies and biological characteristics of the SVF obtained from different methods and volumes of liposuction, regarding a one-step protocol to be followed in experimental and clinical cell-based therapies, in an attempt to optimize possible translational procedures.

\section{Materials and Methods}

The experimental protocol was approved by the Institutional Research Board. 16 women candidates for liposuction, from 20 to 60 years were selected, recording age and Body Mass Index (BMI). All of them were previously informed about the nature of the study, limited to lab protocols, and the obtained tissue would be discharged and could not be reutilized. They were divided in 3 groups, according to the volume of aspirated fat, performed just at the beginning of the surgery - group I: $20.0 \mathrm{~mL}$, group II: $60.0 \mathrm{~mL}$ and group III: $120.0 \mathrm{~mL}$. In each group, 3 samples of the pre-determined volume were obtained by 4 different methods as follows:

1. Manual liposuction with $10.0 \mathrm{~mL}$ Luer-Lok syringe and 2.0 mm blunt tip cannula

2. Manual liposuction with $60.0 \mathrm{~mL}$ syringe and $2.5 \mathrm{~mm}$ cannula

3. Power-Assisted Liposuction (PAL) (Vibrofit ${ }^{\oplus}$ - Faga Medical) set at 3.000 cycles and $3.0 \mathrm{~mm}$ cannula and

4. Suction-Assisted Liposuction (SAL) ( Nevoni 3003 model) and $4.0 \mathrm{~mm}$ cannula

Twelve samples of each method were obtained for analysis $(n=48)$ (Table 1). The samples manually obtained were left in the syringes that were properly capped and the mechanically fat aspirated was collected directly into a sterile fluid collector, avoiding any manipulation or exposition. All samples were obtained from the anterior and lateral abdominal wall, previously infiltrated with a saline and epinephrine at the proportion 1:1 solution in a standard fashion.

\begin{tabular}{|c|c|c|}
\hline Groups/Volumes & Methods & Samples/Patients \\
\hline \multirow{4}{*}{$20 \mathrm{~mL}$} & A-syringe $10 \mathrm{~mL} / 2.0 \mathrm{~mm}$ cannula & $06 / 02$ \\
\hline & B-syringe $60 \mathrm{~mL} / 2.5 \mathrm{~mm}$ cannula & $06 / 02$ \\
\hline & C-PAL/3.0 mm cannula & $03 / 01$ \\
\hline & D-SAL/ $4.0 \mathrm{~mm}$ cannula & $03 / 01$ \\
\hline \multirow{4}{*}{$\begin{array}{l}11 \\
60 \mathrm{~mL}\end{array}$} & A & $03 / 01$ \\
\hline & $B$ & $03 / 01$ \\
\hline & C & $06 / 02$ \\
\hline & D & $03 / 01$ \\
\hline \multirow{4}{*}{$\begin{array}{l}\text { III } \\
120 \mathrm{~mL}\end{array}$} & A & $03 / 01$ \\
\hline & B & $03 / 01$ \\
\hline & C & $03 / 01$ \\
\hline & D & $06 / 02$ \\
\hline Total & & $48 / 16$ \\
\hline
\end{tabular}

Table 1: Distribution of the methods and samples obtained from each group of liposuction, pre-determined by the aspirated volume.

\section{Isolation of SVF}

The samples were mechanically homogenized at the original initial volumes and, as a representative volume for analysis, $10.0 \%$ of the volume was removed, obtaining $2.0 \mathrm{~mL}, 6.0 \mathrm{~mL}$ and $12.0 \mathrm{~mL}$. To each representative volume was added a type IV collagenase (Clostridium hystoliticum - Sigma Aldrich) in a ratio of 1:3 (fat: collagenase). The mixture was incubated at $37.0^{\circ} \mathrm{C}$ at $5.0 \% \mathrm{CO}_{2}$ for 2 hours, followed by centrifugation at $800 \mathrm{~g}$ for 10 minutes at $23.0^{\circ} \mathrm{C}$, obtaining a final pellet corresponding to the SVF. The pellet was resuspended in $10.0 \mathrm{~mL}$ of culture medium and processed as follows:

1) $1.0 \mathrm{~mL}$ was transferred to cell counting, with $10.0 \mu \mathrm{L}$ placed in a Neubauer chamber for quantification in replicates

2) $1.0 \mathrm{~mL}$ was for immunophenotyping analysis and

3) The remainder was transferred to Petakas for cell culture and isolation of the ADSCs for cell growth kinetics and viability studies

\section{Immunophenotype analysis-mesenchymal tissue characterization}

The sample cells were labeled with specific monoclonal antibodies to CD14, CD45, CD49e, CD31, CD29, CD90, CD51/61, CD54, CD166, CD13, anti-HLA-ABC, CD34, CD44, CD105, CD146, CD73, antiHLA-DR PI to designate groups Cell Differentiation (CD) linked to fluorochromes.

\section{Cell viability and quantification}

The SVF cells viability was performed using the "vital dye" trypan blue, which marks only dead cells. The cell frequencies were performed using the Neubauer chamber, based on counting the number of cells in a defined square (n) and extended to the total number of cells at the sample, using the standard formula:

\section{Cellular Concentration $=\mathrm{n} \times$ Dilution factor $\times 10^{4}$}

\section{Culture and expansion of ADSC}

The cells were cultured and expanded in Petakas containing fluid culture medium ALPHA MEM with $10.0 \% \mathrm{v} / \mathrm{v}$ fetal bovine serum and $1.0 \% \mathrm{v} / \mathrm{v}$ of Ampicillin and Streptomycin. After reaching approximately $90.0 \%$ of confluence, the cell lines were "trypsinized" with trypsinEDTA and seeded on another Petaka, with subsequent passages and culture expansions.

\section{Growth kinetics of ADSCs}

For the cell growth kinetics and Population Doubling Time (PDT), cell cultures in Petakas should start from an initial standard concentration of $2.0 \times 10^{5}$. Quantification of living cells by means of trypan blue was performed on days 2-20 for each step of cell expansion, according to the equation below, where 3.32 is a constant value, $\mathrm{Nh}$ is the number of cells collected at the end time $\mathrm{T} 2, \mathrm{Ni}$ is the number of cells inoculated at starting time T1.

$$
\mathrm{PDT}=\frac{1}{3.32 \frac{(\log \mathrm{Nh}-\log \mathrm{Ni})}{(\mathrm{T} 2-\mathrm{T} 1)}}
$$

\section{Statistical analysis}

A database was built in the Microsoft Excel spreadsheet which 
was exported to the statistical programs Minitab 17 and OriginPro 8. A common descriptive statistical analysis was performed with mean and standard deviation values and submitted to Anderson-Darling normality test (with $\mathrm{p}>0.10$ for parametric data). Sample's cell counting on the different lipoaspirates, growth kinetics and relative ADSC quantifications by Immunophenotyping were compared by Pearson statistical test and logistic probability, adopting a significant level above $0.05(\alpha>0.05)$.

\section{Results}

\section{Cells quantification and viability}

There were no statistically significant differences in cell frequencies relative to age and BMI in all groups.

Consistently, the worst cell yielding was obtained with SAL and 4 $\mathrm{mm}$ blunt tip cannulas in all groups. In contrary, the manual method with $10.0 \mathrm{~mL}$ seringe $/ 2.0 \mathrm{~mm}$ cannula and PAL/3.0 $\mathrm{mm}$ cannula showed better cellular SVF extraction in all groups, with no differences statistically significant between them (Figures 1-3). Comparing the average cell frequencies of these best scores, there was an exponencial increase with increasing volumes from 2.900 .000 cells $/ 20 \mathrm{~mL}$ group to $18.500 .000 / 60 \mathrm{~mL}$ group $(6.4 \mathrm{xx})$ and to $380.000 .000 / 120 \mathrm{~mL}$ group (20.5xx).

The average viability was $98.0 \pm 1 \%$ for all samples.

\section{Culture/expansion and growth kinetics of ADSC}

Up to the $9^{\text {th }}$ expansion, the cells exhibited adhesion and proliferation behavior within the Petakas. As the cells were expanded and isolated, the rate of cell growth increased in exponential order, as shown in Figure 4.

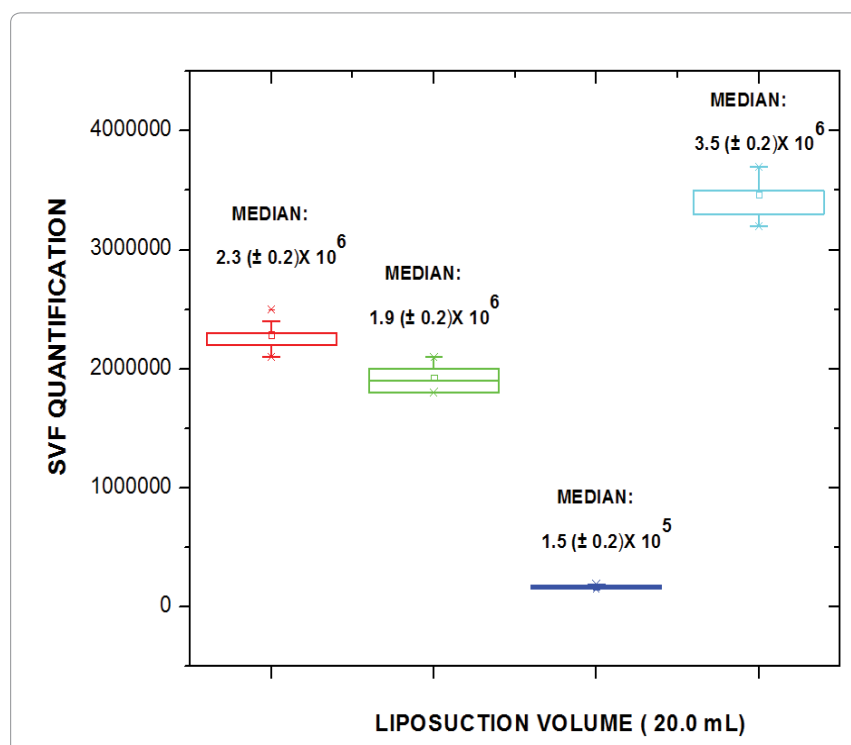

Figure 1: BoxPlot format graphic (OriginPro 8) showing the SVF quantification present in $20.0 \mathrm{~mL}$ of lipoaspirates from different methods, with mean, maximum/minimum values and standard deviation.

RED - Manual $10 \mathrm{~mL}$ syringe $/ 2.0 \mathrm{~mm}$ cannula

GREEN - Manual $60 \mathrm{~mL}$ syringe $/ 2.5 \mathrm{~mm}$ cannula

LIGHT BLUE - Power Assisted Liposuction $/ 3.0 \mathrm{~mm}$ cannula

BLUE - Suction Assisted Liposuction/4.0 mm cannula

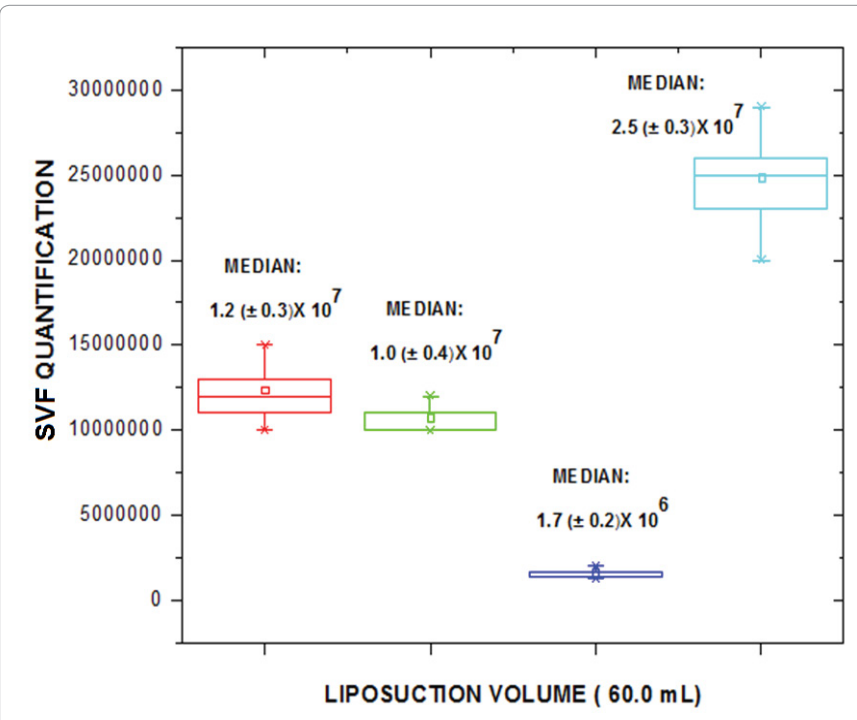

Figure 2: BoxPlot format graphic (OriginPro 8) showing the SVF quantification present in $60.0 \mathrm{~mL}$ of lipoaspirates from different methods, with mean, maximum/minimum values and standard deviation.

RED - Manual $10 \mathrm{~mL}$ syringe $/ 2.0 \mathrm{~mm}$ cannula

GREEN - Manual $60 \mathrm{~mL}$ syringe $/ 2.5 \mathrm{~mm}$ cannula

LIGHT BLUE - Power Assisted Liposuction $/ 3.0 \mathrm{~mm}$ cannula

BLUE - Suction Assisted Liposuction/4.0 mm cannula

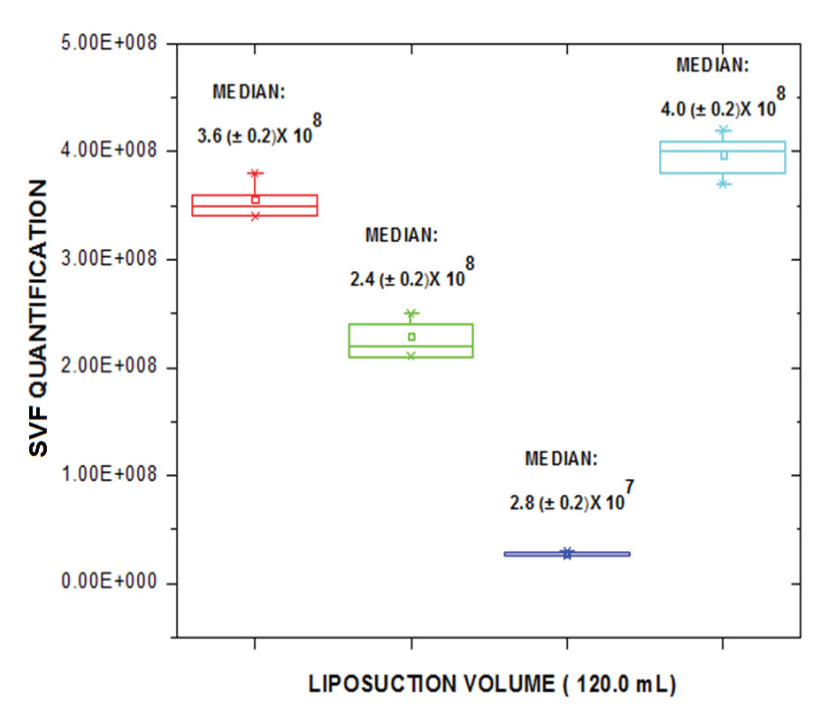

Figure 3: BoxPlot format graphic (OriginPro 8) showing the SVF quantification present in $120.0 \mathrm{~mL}$ of lipoaspirates from different methods, with mean, maximum/minimum values and standard deviation.

RED - Manual $10 \mathrm{~mL}$ syringe/ $2.0 \mathrm{~mm}$ cannula

GREEN - Manual $60 \mathrm{~mL}$ syringe $/ 2.5 \mathrm{~mm}$ cannula

LIGHT BLUE - Power Assisted Liposuction/3.0 mm cannula

BLUE - Suction Assisted Liposuction/4.0 mm cannula

\section{Immunophenotype analysis}

To all samples the cells analyzed by flow cytometry displayed expression of ADSC through specific markers, with mesenchymal cell marker panel being positive for the majority of the labeled antibodies, with the marker CD44 most significant quantitatively. The mean percentage of ADSC in the samples was of $30 \pm 6$ (Figures 5 and 6). 


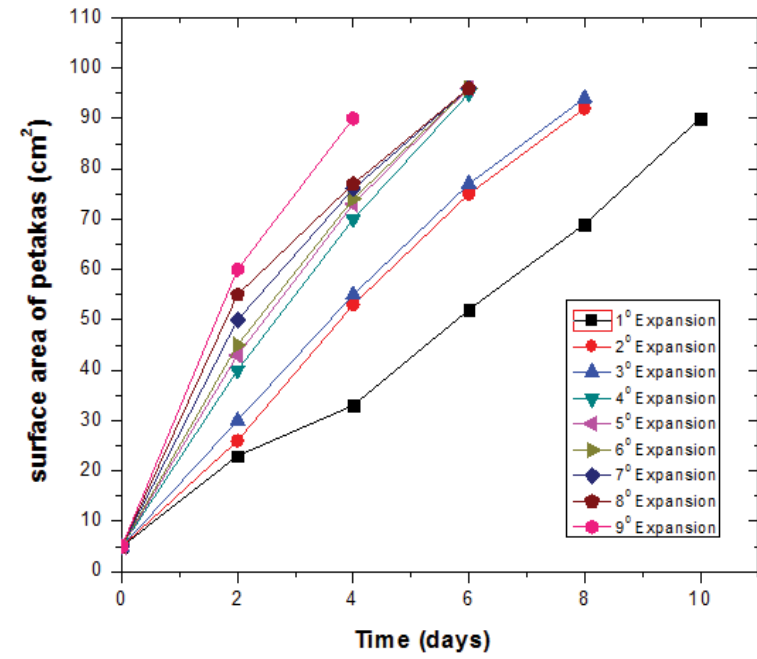

Figure 4: Graphic showing growth kinetics of the isolated adipose mesenchymal stem cells observed in cell culture in Petakas. As the cells were expanded and isolated, the sequential rate of cell growth increased in an exponential order.

\section{Discussion}

In a review article about adipose tissue and stem cells, Ferris, et al. [11] employed an instigating title that translates the way we face adiposity nowadays: "Once fat was fat and that was that". Initially seen just as energy store and short after as a true secretory tissue, now adipose tissue represents a smorgasbord of different functional and stem cells, more properly named as Adipose Tissue Complex [12], changing our concepts relative to fat depots, by now understood under a macro anatomical vision.

Derived from the mesodermal layer, adipose tissue contains a supportive SVF, a heterogeneous undifferentiated mesenchymal cell population that includes not only adipose stromal and hematopoietic stem and progenitor cells but also endothelial cells, fibroblasts, leukocytes, pre-adipocytes and cellular pericytes among others $[13,14]$.

The presented results confirm that all the most common methods of liposuction employed were efficient to harvest the SVF from the subcutaneous layer. The immunophenotyping analysis were in accordance with the statements for mesenchymal tissue characterization [15] and the quality of the cellular population obtained in all samples were similar.

The cellular quantification revealed a superior cellular yield with the manual methods using $10.0 \mathrm{~mL}$ syringe $/ 2.0 \mathrm{~mm}$ cannulas and PAL, optimizing the choice method in this direction, with important clinical relevance.

In terms of cell frequencies, one could speculate that the use of smaller cannulas promotes a greater adipose tissue fragmentation, resulting in a relative higher surface area of adipocytes fractions and its corresponding vascular fraction, allowing an increased enzymatic activity to extract the SVF. According to Kurita, et al., [16] ADSCs did not shift between the adipose and fluid portions just by centrifugation, likely because ADSCs are resident in or strongly adhered to the adipose tissues. This also could be related to the concept of "bloody niche", where adipose stem cells are found in the wall of blood vessels that supply white adipose depots but are absent from blood vessels that supply other
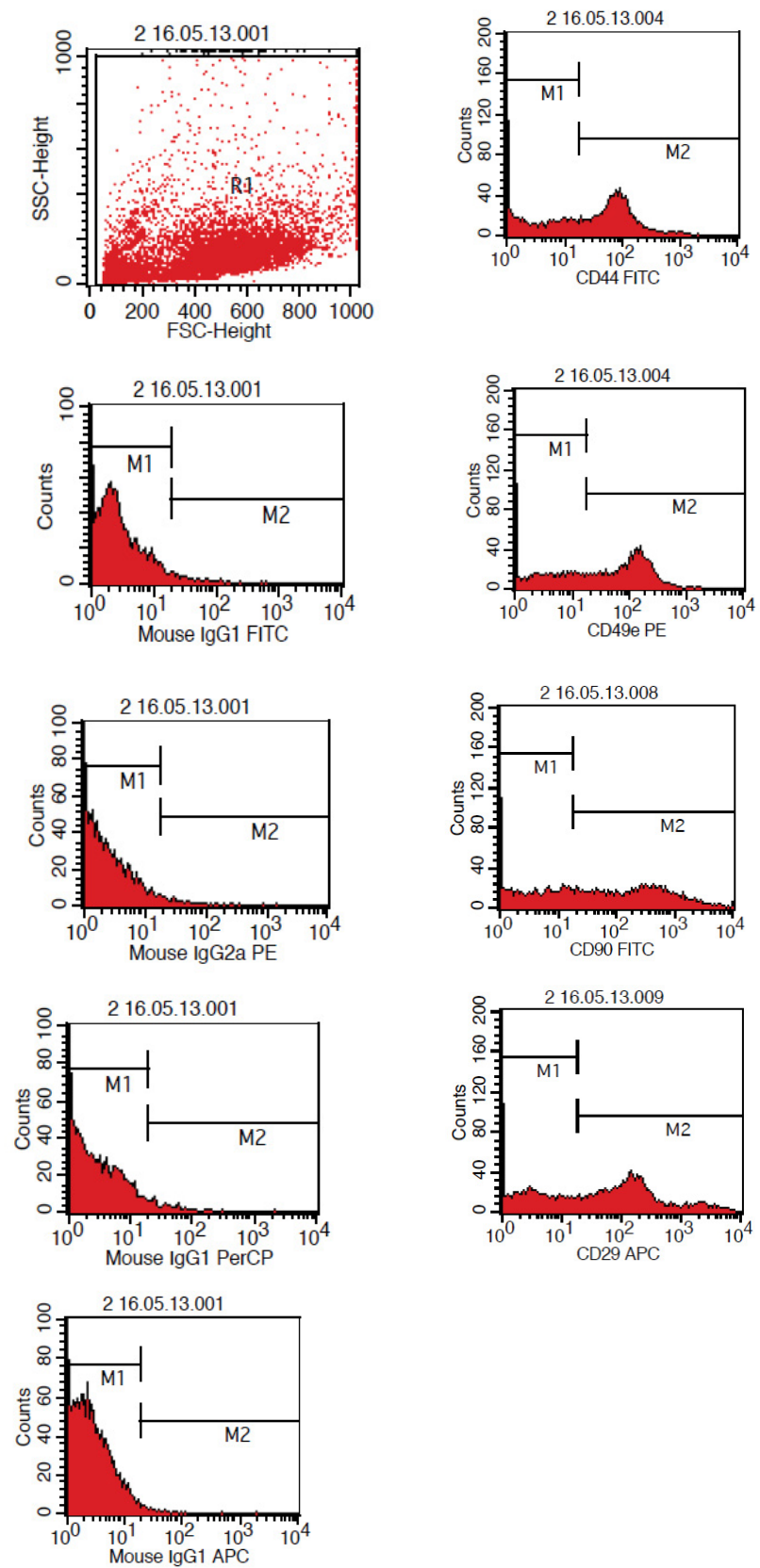

Figure 5: Common graphic of ADSC values present in the SVF initial solution analyzed by quantitative immunophenotyping with the markers CD45, CD14, CD51, CD61, CD54, CD44, CD49e, CD34, CD13, CD31, CD166, HLA-DR, HLA-ABC, CD29, CD146, CD90, CD105, CD106 and CD73, extracted using four different techniques for sampling. Panel showing mesenchymal phenotypic characteristics of ADSC, where $M 1$ is negative markings and $M 2$ represents the positive reactions of antibodies. The ADSC are positive for CD13, CD29, CD44, CD54, CD90, CD146, CD166, CD49e, CD31, CD73 and CD105. The first graph shows granularity (SSC) versus size (FSC) of ADSC.

tissues [17]. Still speculating, the same interpretation could explain the results with PAL, the emulsification promoted by the technique [18] would facilitate the cellular extraction, a mechanical component to be better understood.

The use of larger cannulas and high negative pressure methods 


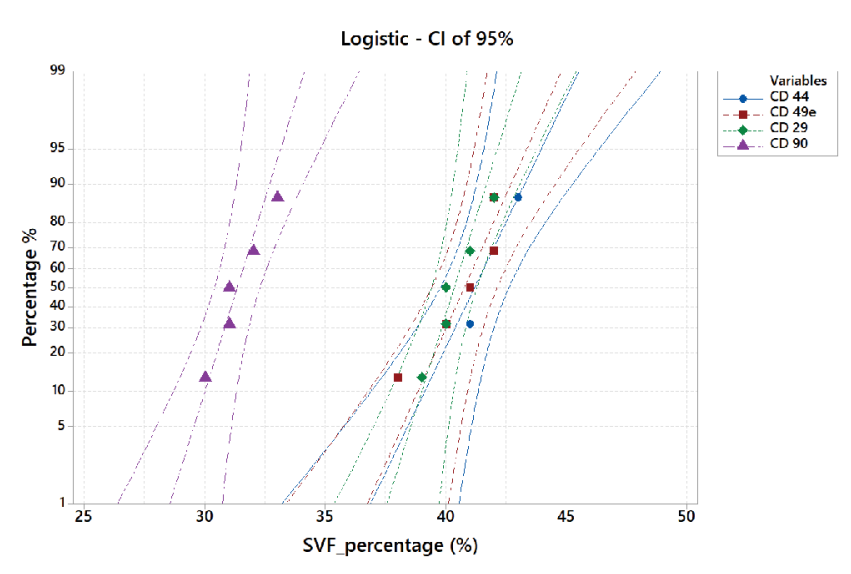

Figure 6: Logistic probability graph showing the distribution of the values obtained in percentage of the main markers of mesenchymal stem cells present in the SVF. The mean of ADSC in the samples was of $30 \pm 6 \%$.

obviously can improve the harvesting volume/time ratio, but also produces more tissue damage and is less selective, increasing the presence of blood and interstitial tissue in the samples, besides the presence of larger clusters of fat, possibly hindering the enzymatic laboratorial processes or even a mechanical dissociation for cell extraction. Another aspect could be related to the barometric forces, as described by Mojallal, et al. [19], stating that pump-assisted technologies could decrease the viability of nucleated cells and also showing superior cell yielding of SVF using PAL.

Still controversial, the anatomical donor site could impact the cell frequencies on the samples. All samples of this study were obtained from the abdominal wall, described as a superior donor site in other studies $[20,21]$.

Increasing volumes in fact give us an exponential yield on cell frequencies in the average of the best methods reported from 2.900 .000 cells $/ 20 \mathrm{~mL}$ samples up to 380.000 .000 cells $/ 120 \mathrm{~mL}$ samples remembering that this population corresponds to the estimated total SVF cellular population. For therapeutic purposes we still don't know what this means exactly, but it seems that by now the prevailing philosophy is "more is better" and we may just to compare cells frequencies and methods' efficacy.

The first aspect to be considered, for intended one step procedure, is that this counting refers to all non-buoyant cellular fraction represented by the final pellet obtained. Studies have estimated that lipoaspirates provides ADSCs at a frequency up to 1:1.500 cells, exceeding the frequency of Mesenchymal Stem Cells (MSCs) from bone marrow 500 to 1000 fold, with $1 \mathrm{~g}$ of adipose tissue yielding nearly 5.000 ADSCs [22]. A bone marrow transplant of $100 \mathrm{~mL}$ contains an average of $6 \times$ $10^{8}$ nucleated cells, but only 0.001 to $0.01 \%$ corresponds to stem cells [23]. Suga, et al. [24], analyzing lipoaspirates obtained from SAL and $2.5 \mathrm{~mm}$ cannulas, reported that the ratio of adipose stromal cells to adipocytes was found to be much larger than previously described, estimating an adipocyte number of 1 million per $1 \mathrm{~mL}$ of suctioned adipose tissue, with $37.0 \%$ of ADSCs and speculating that this number in intact adipose tissue may be similar to that of adipocytes.

The cell frequencies and relative average ADSCs in the samples in this study (30.0\%) are on pair with these more recent reports, but with an important difference relative to the volumes employed. Tabit, et al.
[25] states a minimum starting lipoaspirate volume of $250 \mathrm{~mL}$ required for a sufficient yield of ASCs, expecting $1 \times 10^{7}$ to $1 \times 10^{8}$ ADSCs from this volume. Jurgen, et al. [26] reported 2.6 to $10.2 \times 10^{6}$ stem cells from $100 \mathrm{~g}$ of adipose tissue, stating that this amount appears to be sufficient for cell based therapies and that the yield of ADSCs is dependent on the tissue-harvesting site. Without setting numbers, Varma, et al. [27] reported that "Large volumes achieved with tumescent liposuction are needed to obtain enough ASCs in the operating room without the need for laboratory expansion". An important range in cell frequencies for total SVF and isolated ADSCs is observed in the reported studies, reflecting the lack of fully defined guidelines to the laboratorial protocols to optimize the cell extraction. Anyway, it's obvious that any one step procedure requires an SVF isolation containing sufficient progenitor cells with regenerative potential, a "gold number" which still remains unknown.

At the employed protocol, 2 main differences should be addressed:

1. The samples were not previously washed in a Phosphate Buffer Solution (PBS) as usually performed and the entire sample (the saline and the fatty portions) is processed after homogenization

\section{Enzymatic digestion was employed a collagenase type IV enzyme}

The first idea is to enhance the cellular concentration at the final pellet, preserving the fluid portions of the aspirates without a previous washing. This fluid portion is composed by the saline solution preoperatively injected, peripheral blood and cellular fractions from the subcutaneous layer, with a reported population of ADSCs [7]. Yoshimura, et al. [28] reported a comparable amount of ADSCs harvested from the fatty and fluid portions of lipoaspirates, showing that most of the fluid portion derived cells have similar surface markers, suggesting that they correspond to the same population derived from adipose portion. The presence of these cells seems to be related to the pericytes, i.e., perivascular cells associated with capillaries and microvessels which build up the vasculature in different tissues, including white adipose tissue that natively express MSC markers [29], supporting the hypothesis that an ancestor of the MSC is natively associated with the blood vessels wall [30].

Thus, is logical to speculate that these cells could be released into the fluid by the natural mechanical tissue injury during the liposuction. Considering this aspect and the literature discussed, the findings obtained suggest that different mechanical stresses over the subcutaneous tissue may impact the cell yielding of the resident SVF and its cellular subpopulations, a component not discussed in literature, focused in volumes and harvested sites. A similar concept has been described with the nano-fatgrafting technique, were the $e x$ vivo mechanical emulsification of lipoaspirates resulted in a SVF with higher proportions of progenitor, mesenchymal and multilineage cells, a stress induction that may enhance the regenerative potential of the non-expanded pellet [31].

Collagenase Clostridium histolyticum enzymatic digestion is the gold standard to almost all protocols for extracting the SVF from adipose tissue since Rodbell and Jones [32,33], and the collagenase type I is commonly employed for preliminary digestions [34]. The collagenase type IV was employed in a modified protocol by Yokomizo, et al. $[35,36]$, where they observed a better performance of the cell extraction and confirmed in another study [37].

The relevance of this finding is limited by the guidelines governing the practical application of cell-based therapies $[5,38]$ where enzymatic digestion has been considered to be more than minimally manipulated 
procedure [39]. Initially expected as temporary, allowed in some countries and even incorporated to automatic devices [40], these restrictions probably are likely to remain in the long term, limiting their applications to non-human mammals, thus compromising a translational character [41,42]. Facing this, we've decided to adopt exclusively mechanical and enzymatic-free methods in future protocols [43].

Additional restrictions are imposed by primary operational rules defined as "Good Manufacturing Practices" and "Good Laboratory Practices" $[44,45]$ to cell manufacture process, limiting the widespread application of standard protocols in a worldwide basis. In addition, restrictions are also reported about the common use of Fetal Bovine Serum in culture media [46], possible cellular karyotypic changes after sequential passages and contamination of the cellular populations [47].

The SVF direct use on cellular therapies seems to be, in the short term, the smartest strategy to widespread translational research in the regenerative medicine field. It's regenerative potential has been demonstrated in numerous diseases and applications [48-50] with similar therapeutic effects of ADSCs [51-53].

In addition, the preservation of the extracted SVF microenvironment could eventually favor its biological activity at the transplanted site, referring to the niche hypothesis concepts, were the stem cells itself, extracellular matrix and cell adhesion components among others factors have an important role to provide adequate physiological cues $[54,55]$, with its biological behavior also being influenced by their local milieu [56].

\section{Conclusion}

The mechanical stress applied over the subcutaneous tissue may impact the cell yielding of the extracted SVF. Syringes with small cannulas $(2.0 \mathrm{~mm})$, and/or in-vivo emulsification of the adipose tissue through PAL seem to have a positive effect, optimizing future liposuction protocols. Further studies must address this stress induction aspect, as well as the cellular viability in such procedures. To obtain a translational character and using the SVF as therapeutic option, in the short term the one-step protocols must be focused on mechanical and enzymatic-free methods for cell extraction. To properly accomplish this, future studies should fulfill some important basic gaps in the scientific literature, citing mainly:

1) Establish a minimal cellular population required to therapeutic effects in cell based therapies

2) Confirm the SVF regenerative properties comparing its efficacy relative to isolated ADSCs and

3) Improve the actual rudimentary understanding of the concepts beyond the niche hypothesis and interactions of a regenerative cell mix on transplanted sites

\section{Acknowledgment}

We thank all support of the Heart Hospital-Institute of Cardiovascular Diseases of Sao Jose do Rio Preto-SP, (HC-IMC) Sao Paulo, Brazil.

\section{Fundingt}

The present study had the financial support of the Heart Hospital-Institute of Cardiovascular Diseases of São José do Rio Preto-SP (HC-IMC) and Clinical Director-Frascino Institute of Plastic Surgery of São José do Rio Preto-SP.

\section{Conflict of Interests}

There is no conflict of interest between authors.

\section{References}

1. Zuk PA, Zhu M, Ashjian P, De Ugarte DA, Huang Jl, et al. (2002) Human adipose tissue is a source of multipotent stem cells. Mol Biol Cell 13: 42794295. [PubMed]

2. Rahman A, Anjum S (2017) Frontiers in stem cells and regenerative medicine research. Bentham Science Publishers, Vol. 1-7.

3. Flynn TC, Coleman WP, Field LM, Klein JA, Hanke CW, et al. (2000) History of liposuction. Dermatol Surg 26: 515-520.

4. Billings E, May JW (1989) Historical review and present status of free fat graft autotransplantation in plastic and reconstructive surgery. Plast Reconst Surg 83: 368-381. [PubMed]

5. Halme DG, Kessler DA (2006) FDA regulation of stem-cell based therapies. N Engl J Med 355: 1730-1735. [PubMed]

6. Casadei A, Epis R, Ferroni L, Tocco I, Gardin C, et al. (2012) Adipose tissue regeneration: A state of the art. J Biomed Biotechnol 2012: 1-12.

7. Eom YW, Lee JE, Yang MS, Jang IK, Kim HE, et al. (2011) Rapid isolation of adipose tissue-derived stem cells by the storage of lipoaspirates. Yonsei Med J 52: 999-1007. [PubMed]

8. Francis MP, Sachs PC, Elmore LW, Holt SE (2010) Isolating adipose-derived mesenchymal stem cells from lipoaspirate blood and saline fractions. Organogenesis 6: 11-14. [PubMed]

9. Lee JM, Moon KC, Han SH, Jeong SH, Kim WK (2013) What tissue is formed after graft of adipose-derived stromal vascular fraction cells? J Craniofac Surg 24: 636-639. [PubMed]

10. Carvalho PP, Gimble JM, Dias IR, Gomes ME, Reis RL (2013) Xenofree enzymatic products for the isolation of human adipose-derived stromal/stem cells. Tissue Eng Part C Methods 19: 473-478. [PubMed]

11. Ferris WF, Crowther NJ (2011) Once fat was fat and that was that: our changing perspectives on adipose tissue. Cardiov J Africa 22: 147-154. [PubMed]

12. Alexander RW (2012) Understanding Adipose-derived Stromal Vascular Fraction (AD-SVF) cell biology and use on the basis of cellular, chemical, structural and paracrine components: a concise review. Journal of Prolotherapy 4: e855-e869.

13. Prunet-Marcassus B, Cousin B, Caton D, Andre M, Penicaud L, et al. (2006) From heterogeneity to plasticity in adipose tissues: site-specific differences. Exp Cell Res 312: 727-736. [PubMed]

14. Han J, Koh YJ, Moon HR, Ryoo HG, Cho CH, et al. (2010) Adipose tissue is an extramedullary reservoir for functional hematopoietic stem and progenitor cells. Blood 115: 957-964. [PubMed]

15. Bourin P, Bunnell BA, Casteilla L, Dominici M, Katz AJ, et al. (2013) Stromal cells from the adipose tissue-derived stromal vascular fraction and culture expanded adipose tissue-derived stromal/stem cells: a joint statement of the International Federation for Adipose Therapeutics and Science (IFATS) and the International Society for Cellular Therapy (ISCT). Cytotherapy 15: 641-648. [PubMed]

16. Kurita M, Matsumoto D, Shigeura T, Sato K, Gonda K, et al. (2008) Influences of centrifugation on cells and tissues in liposuction aspirates: optimized centrifugation for lipotransfer and cell isolation. Plast Reconstr Surg 121: 10331041. [PubMed]

17. Tang W, Zeve D, Suh JM, Bosnakovski, Kyba M, et al. (2008) White fat progenitor cells reside in the adipose vasculature. Science 322: 583-586. [PubMed]

18. Fodor PB (2005) Power-assisted lipoplasty versus traditional suction-assisted lipoplasty: comparative evaluation and analysis of output. Aesthetic Plast Surg 29: 49-52. [PubMed]

19. Mojallal A, Auxenfans C, Lequeux C, Braye F, Damour O (2008) Influence of negative pressure when harvesting adipose tissue on cell yield of the stromalvascular fraction. Biomed Mater Eng 18: 193-197. [PubMed]

20. Padoin AV, Braga-Silva J, Martins P, Rezende K, Rezende AR, et al. (2008) Sources of processed lipoaspirate cells: influence of donor site on cell concentration. Plast Reconst Surg 122: 614-618. [PubMed]

21. lyyanki T, Hubenak J, Liu J, Chang El, Beahm EK, et al. (2015) Harvesting technique affects adipose-derived stem cell yield. Aesthet Surg J 35: 467-476. [PubMed] 
Citation: Frascino LF, Filho IJZ (2018) Quantitative and Qualitative Analysis of Human Stromal Vascular Fraction from Different Methods of Liposuction Short Title: Stromal Fraction from Liposuction Types. Stem Cell Res Ther 8: 439. doi: 10.4172/2157-7633.1000439

22. De Ugarte DA, Morizono K, Elbarbary A, Alfonso Z, Zuk PA, et al. (2003) Comparison of multi-lineage cells from human adipose tissue and bone marrow. Cells Tissues Organs 174: 101-109. [PubMed]

23. Pittenger MF, Mosca JD, McIntosh KR (2000) Human mesenchymal stem cells: progenitor cells for cartilage, bone, fat and stroma. Curr Top Microbiol Immunol 251: 3-11. [PubMed]

24. Suga $H$, Matsumoto $D$, Inoue $K$, Shigeura T, Eto $H$, et al. (2008) Numerical measurements of viable and nonviable adypocites and other cellular components in aspirated fat tissue. Plast Reconstr Surg 122: 103-114. [PubMed]

25. Tabit CJ, Slack GC, Fan K, Wan DC, Bradley JP (2012) Fat grafting versus adipose-derived stem cell therapy: distinguishing indications, techniques, and outcomes. Aesthetic Plast Surg 36: 704-713. [PubMed]

26. Jurgens WJFM, Oedayrajsingh-Varma MJ, Helder MN, Zandiehdoulabi B Schouten TE, et al. (2008) Effect of tissue-harvesting site on yield of stem cells derived from adipose tissue: implications for cell-based therapies. Cell Tissue Res 332: 415-426. [PubMed]

27. Oedayrajsingh-Varma MJ, van Ham SM, Knippenberg M, Helder MN, KleinNulend J, et al. (2006) Adipose tissue-derived mesenchymal stem cell yield and growth characteristics are affected by the tissue-harvesting procedure. Cytotherapy 8: 166-177. [PubMed]

28. Yoshimura K, Shigeura T, Matsumoto D, Sato T, Takaki Y, et al. (2006) Characterization of freshly isolated and cultured cells derived from the fatty and fluid portions of liposuction aspirates. J Cell Physiol 208: 64-76. [PubMed]

29. Crisan M, Yap S, Casteilla L, Chen CW, Corselli M, et al. (2008) A perivascular origin for mesenchymal stem cells in multiple human organs. Cell Stem Cell 3: 301-313. [PubMed]

30. da Silva Meirelles L, Caplan AI, Nardi NB (2008) In search of the in vivo identity of mesenchymal stem cells. Stem Cells 26: 2287-2299. [PubMed]

31. Banyard DA, Sarantopoulos CN, Borovikova AA, Qiu X, Wirth GA, et al. (2016) Phenotypic analysis of stromal vascular fraction after mechanical shear reveals stress-induced progenitor populations. Plast Reconstr Surg 138: 237-247. [PubMed]

32. Rodbell M (1966) Metabolism of isolated fat cells. II. The similar effects of phospholipase $\mathrm{C}$ (Clostridium perfringens alpha toxin) and of insulin on glucose and amino acid metabolism. J Biol Chem 241: 130-139. [PubMed]

33. Rodbell M, Jones AB (1966) Metabolism of isolated fat cells. The similar inhibitory action of phospholipase $\mathrm{C}$ (Clostridium perfringens alpha toxin) and of insulin on lipolysis stimulated by lipolytic hormones and theophylline. J Biol Chem 241: 140-142. [PubMed]

34. Zuk PA, Zhu M, Mizuno H, Huang J, Futrell JW, et al. (2001) Multilineage cells from human adipose tissue: implications for cell-based therapies. Tissue Eng 7: 211-328. [PubMed]

35. Yokomizo VMF, Benemond TMH, Bressan FF, Sangalli JR, Pieiri NCG, et al. (2011) Adipose tissue derived stem cells: isolation, in vitro culture and potential uses in dermatology. Surg Cosmet Dermatol 3: 55-59.

36. Bressan FF (2013) Generation of pluripotent cells through gene induction and nuclear transfer: a bovine model of pluripotency. Tese (Doutorado) Faculdade de Zootecnia e Engenharia de Alimentos, Universidade de São Paulo.

37. Zotarelli Filho IJ, Frascino LF, Greco OT, Araújo JD, Bilaqui A, et al. (2013) Chitosan-collagen scaffolds can regulate the biological activities of adipose mesenchymal stem cells for tissue engineering. J Regen Med Tissue Eng 2: $1-10$.

38. Food and Drug Administration (2015) Human cells, tissues, and cellular and tissue-based products (HCT/Ps) from adipose tissue: regulatory considerations Draft Guidance for Industry; Availability. The Daily Journal of the United States Government.

39. Human cells, tissues, and cellular and tissue-based products. Code of Federal Regulations. (2011) 21CFR127 1.3(f).

40. Hicok KC, Hedrick MH (2011) Automated isolation and processing of adiposederived stem and regenerative cells. Methods Mol Biol 702: 87-105. [PubMed]

41. Williams SK, McKenney S, Jarrell BE (1995) Collagenase lot selection and purification for adipose tissue digestion. Cell Transplant 4: 281-289. [PubMed]

42. Gimble JM, Bunnell BA, Chiu ES, Guilak F (2011) Concise review: Adiposederived stromal vascular fraction cells and stem cells: let's not get lost in translation. Stem Cells 29: 749-754. [PubMed]

43. Chaput B, Bertheuil N, Escubeset M, et al. (2016) Mechanically isolated stroma vascular fraction provides a valid and useful collagenase-free alternative technique: a comparative study. Plast Reconstr Surg 138: 807-819. [PubMed]

44. Sensebe L, Bourin P, Tarte K (2011) Good manufacturing practices production of mesenchymal stem/stromal cells. Hum Gene Ther 22: 19-26. [PubMed]

45. Dietz AB, Padley DJ, Gastineau DA (2007) Infrastructure development for human cell therapy translation. Clin Pharmacol Ther 82: 320-324. [PubMed]

46. Lindroos B, Aho KL, Kuokkanen H, Raty S, Huhtala H, et al. (2010) Differentia gene expression in adipose stem cells cultured in allogeneic human serum versus fetal bovine serum. Tissue Eng Part A 16: 2281-2294. [PubMed]

47. ISSCR (2016) Guidelines for stem cell research and clinical translation. pp. $1-37$.

48. Nguyen A, Guo J, Banyard DA, Fadavi D, Toranto JD, et al. (2016) Stromal vascular fraction: A regenerative reality? Part 1: Current concepts and review of the literature. J Plast Reconst Aesthetic Surg 69: 170-179. [PubMed]

49. Mohammadi R, Sanaei N, Ahsan S, Rostami H, Abbasipour-Dalivand S, et al. (2014) Repair of nerve defect with chitosan graft supplemented by uncultured characterized stromal vascular fraction in streptozotocin induced diabetic rats. Int J Surg 12: 33-40. [PubMed]

50. U.S. National Library of Medicine - ClinicalTrials.gov.

51. van Dijk A, Naaijkens BA, Jurgens WJ, Nalliah K, Sairras S, et al. (2011) Reduction of infarct size by intravenous injection of uncultured adipose derived stromal cells in a rat model is dependent on the time point of application. Stem Cell Res 7: 219-229. [PubMed]

52. Jurgens WJ, Kroeze RJ, Zandieh-Doulabi B, van Dijk A, Renders GA, et al. (2013) One-step surgical procedure for the treatment of osteochondral defects with adipose-derived stem cells in a caprine knee defect: a pilot study. Biores Open Access 2: 315-325. [PubMed]

53. Barba M, Cicione C, Bernardini C, Michetti F, Lattanzi W (2013) Adiposederived mesenchymal cells for bone regereneration: state of the art. Biomed Res Int 2013: 416391. [PubMed]

54. Jones DL, Wagers AJ (2008) No place like home: anatomy and function of the stem cell niche. Nat Ver Mol Cell Bio 9: 11-21. [PubMed]

55. Kim WS, Han J, Hwang SJ, Sung JH (2014) An update on niche composition, signaling and functional regulation of the adipose-derived stem cells. Expert Opin Biol Ther 14: 1091-1102. [PubMed]

56. Guo J, Nguyen A, Banyard DA, Fadavi D, Toranto JD, et al. (2016) Stroma Vascular Fraction: A regenerative reality? Part 2: Mechanisms of regenerative action. J Plast Reconstr Aesthet Surg 69: 180-188. [PubMed] 